Article

\title{
Kishonite, $\mathrm{VH}_{2}$, and Oreillyite, $\mathrm{Cr}_{2} \mathrm{~N}$, Two New Minerals from the Corundum Xenocrysts of $\mathrm{Mt}$ Carmel, Northern Israel
}

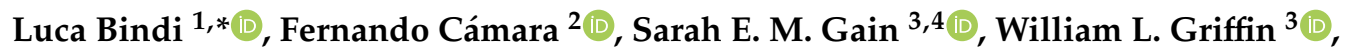 \\ Jin-Xiang Huang ${ }^{3} \mathbb{D}$, Martin Saunders ${ }^{4} \mathbb{D}$ and Vered Toledo ${ }^{5}$ \\ 1 Dipartimento di Scienze della Terra, Università degli Studi di Firenze, Via G. La Pira 4, I-50121 Firenze, Italy \\ 2 Dipartimento di Scienze della Terra 'A. Desio', Università degli Studi di Milano, Via L. Mangiagalli 34, \\ I-20133 Milano, Italy; fernando.camara@unimi.it \\ 3 Australian Research Council Centre of Excellence for Core to Crust Fluid Systems (CCFS) and GEMOC, \\ Earth and Planetary Sciences, Macquarie University, Sydney, NSW 2109, Australia; \\ sarah.gain@mq.edu.au (S.E.M.G.); bill.griffin@mq.edu.au (W.L.G.); jinxiang.huang@mq.edu.au (J.-X.H.) \\ 4 Centre for Microscopy, Characterisation and Analysis, The University of Western Australia, \\ Perth, WA 6009, Australia; martin.saunders@uwa.edu.au \\ 5 Shefa Gems, Netanya 4210602, Israel; vered@shefagems.com \\ * Correspondence: luca.bindi@unifi.it; Tel.: +39-055-2757532
}

Received: 17 November 2020; Accepted: 11 December 2020; Published: 13 December 2020

\begin{abstract}
Here, we describe two new minerals, kishonite $\left(\mathrm{VH}_{2}\right)$ and oreillyite $\left(\mathrm{Cr}_{2} \mathrm{~N}\right)$, found in xenoliths occurring in pyroclastic ejecta of small Cretaceous basaltic volcanoes exposed on Mount Carmel, Northern Israel. Kishonite was studied by single-crystal X-ray diffraction and was found to be cubic, space group $F m \overline{3} m$, with $a=4.2680(10) \AA, V=77.75(3) \AA^{3}$, and $Z=4$. Oreillyite was studied by both single-crystal $X$-ray diffraction and transmission electron microscopy and was found to be trigonal, space group $P \overline{3} 1 m$, with $a=4.7853(5) \AA, c=4.4630(6) \AA, V=88.51 \AA^{3}$, and $Z=3$. The presence of such a mineralization in these xenoliths supports the idea of the presence of reduced fluids in the sublithospheric mantle influencing the transport of volatile species (e.g., C, H) from the deep Earth to the surface. The minerals and their names have been approved by the Commission of New Minerals, Nomenclature and Classification of the International Mineralogical Association (No. 2020-023 and 2020-030a).
\end{abstract}

Keywords: kishonite; oreillyite; hydride; nitride; corundum xenolith; reducing conditions; Mt Carmel; Israel

\section{Introduction}

The study of the xenoliths occurring in pyroclastic ejecta of small Cretaceous basaltic volcanoes exposed on Mt Carmel [1-8] has revealed a very peculiar, exotic and ultra-reduced mineral assemblage reflecting the interaction of deep-seated basaltic magmas with mantle-derived $\mathrm{CH}_{4}+\mathrm{H}_{2}$ at high fluid/melt ratios. During these ongoing studies, two new minerals, kishonite $\left(\mathrm{VH}_{2}\right)$ and oreillyite $\left(\mathrm{Cr}_{2} \mathrm{~N}\right)$ have been identified and are described here.

The sample containing kishonite was recovered from bulk alluvial samples in the Kishon Mid Reach Zone 2. These are part of a xenolith assemblage that includes coarse-grained aggregates of hibonite + grossite + spinel assemblages that carry inclusions of $\mathrm{V}^{0}$ and $\mathrm{V}$-Al alloys, indicating $f \mathrm{O}_{2}$ down to $\leq \Delta \mathrm{IW}-9[4]$. 
The sample containing oreillyite was recovered from the Kishon Mid Reach Zone 1 and consists of a $1.7 \mathrm{~mm}$ crystal of corundum with a hollow centre and raised rims, indicating hopper growth, and it has an intense purple-red colour [5].

The name kishonite is for the Kishon river, which drains Mt Carmel and enters the sea near Haifa in Northern Israel (and where the placer gemstone deposits with the studied xenoliths are located), whereas oreillyite honours Suzanne O'Reilly (born 1946), professor in Geology at Macquarie University, Sydney, Australia, Director of the ARC National Key Centre for Geochemical Evolution and Metallogeny of Continents (GEMOC) and Director of the ARC Centre of Excellence for Core to Crust Fluid Systems (CCFS).

Both new minerals and mineral names have been approved by the Commission on New Minerals, Nomenclature and Classification of the International Mineralogical Association (No. 2020-023 and 2020-030a for kishonite and oreillyite, respectively). Holotypes are deposited in the collections of the Museo di Storia Naturale, Università degli Studi di Firenze, Firenze, Italy, catalogue number 3364/I. Oreillyite is also deposited at the Centre for Microscopy, Characterization and Analysis, The University of Western Australia, Australia, catalogue number 1174-C_FF.

\section{Description and Physical Properties}

Kishonite occurs as one subhedral single crystal, $17 \times 25 \times 38 \mu \mathrm{m}$ (Figure 1), which is the holotype material. It is opaque. Colour, luster, streak, hardness, tenacity, cleavage, fracture, density, and optical properties could not be determined because of the small grain size.

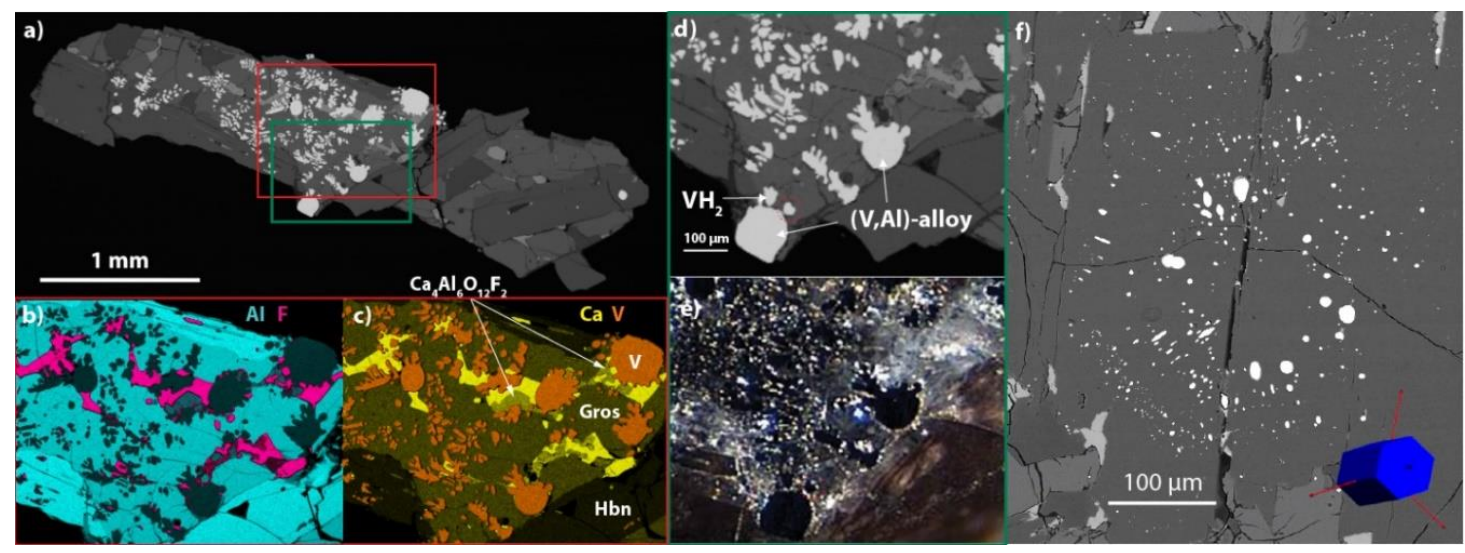

Figure 1. Images of the rock fragment from Mt Carmel. (a) Back-scattered electron (BSE) image of the hibonite-grossite-spinel aggregate studied. The red box indicates the region enlarged in (b) and (c), which reports X-ray compositional maps, and the green box shows the region enlarged in (d) a BSE image; arrows mark the (V,Al)-alloys and the $\mathrm{VH}_{2}$ fragment (kishonite) that was sampled. (e) Transmitted-light photo (plane polars) of the same rock sample, showing inclusions of metallic vanadium in platy hibonite crystals. (f) BSE image of a typical hibonite crystal showing the zonal distribution of vanadium and (V,Al)-alloys on crystal faces. Crystal orientation is shown by the blue hexagonal prism.

Calculated density is $4.523 \mathrm{~g} \cdot \mathrm{cm}^{-3}$, using the empirical formula and X-ray single-crystal data (see below). Kishonite is associated with hibonite, grossite, spinel, vanadium, and V-Al alloys. A more detailed description of the kishonite occurrence is given by Bindi et al. [9].

Oreillyite occurs as one subhedral volume sandwiched between corundum and native chromium (Figure 2), which is the holotype material. 


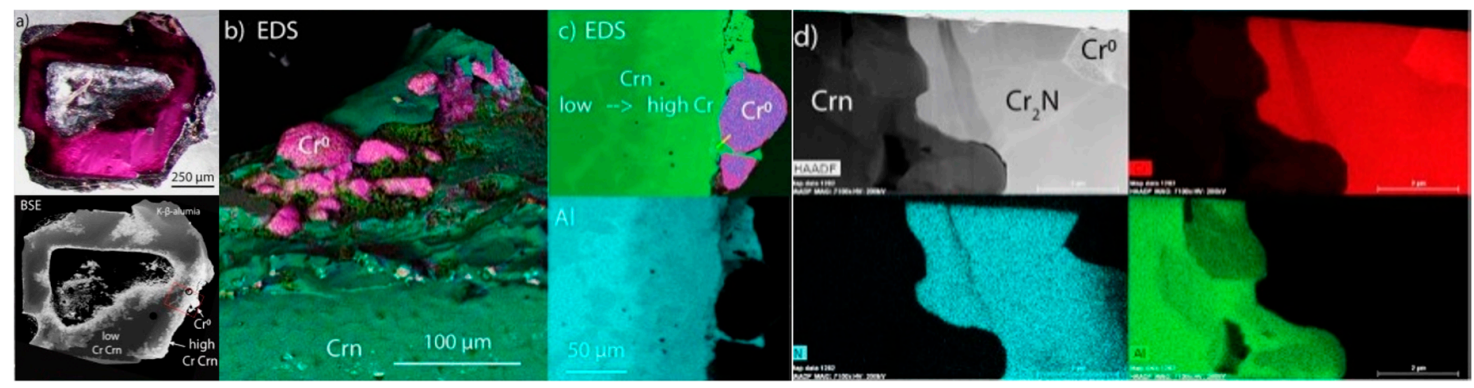

Figure 2. Images of sample 1174C. (a) BSE image and transmitted-light photomicrograph showing colour, and distribution of highest-Cr parts (light areas in BSE). Note ball of chromium $\left(\mathrm{Cr}^{0}\right)$ on edge of crystal. (b) 3D oblique view and compositional map of the surface of $1174 \mathrm{C}$ before sectioning. Rough dark green in lower part of the image is the ruby; smooth dark green in the upper part is kahlenbergite $\left(\mathrm{KAl}_{11} \mathrm{O}_{17}\right)$. Small bright grains along rim of crystal in middle of image are Ni-bearing iron. Bright pink-purple "mushrooms" are chromium. (c) Phase map and Al map of the contact between the largest $\mathrm{Cr}$ ball, showing higher $\mathrm{Cr}$ (lower $\mathrm{Al}$ ) toward the $\mathrm{Cr}$ ball, and the compositional granularity of the high-Cr zone. (d) TEM-BSE image and element maps of FIB foil across contact between chromium and $\mathrm{Cr}$-rich corundum, separated by a zone of oreillyite (scale bar indicates $2 \mu \mathrm{m}$ ). Note granularity in the $\mathrm{Cr}$ and $\mathrm{Al}$ maps of the corundum, interpreted as the result of spinodal breakdown.

Colour, lustre, streak, hardness, tenacity, cleavage, fracture, density, and optical properties could not be determined because of the small grain size. Calculated density is $6.64 \mathrm{~g} \cdot \mathrm{cm}^{-3}$ using the ideal formula and the unit-cell volume of the triple ordered cell $(Z=3$; see below).

\section{Chemical Composition}

Quantitative elemental microanalyses of the type grain of kishonite were carried out using a CAMECA 100× electron microprobe (WDS mode, $15 \mathrm{kV}$ and $10 \mathrm{nA}, 1 \mu \mathrm{m}$ beam size, counting times $20 \mathrm{~s}$ for peak and $10 \mathrm{~s}$ for background; Gennevilliers, France). Analyses were processed with the CITZAF correction procedure and gave average values of (in wt.\% of elements): V 93.71 and $\mathrm{Al} 2.61$. Metallic vanadium and aluminium were used as standard [9]. Hydrogen was not measured (given the rarity of the phase), and the stoichiometry is given on the basis of the high-quality single-crystal $\mathrm{X}$-ray refinement (see below). The $\mathrm{VH}_{2}$ ideal formula requires $\mathrm{V} 96.19$ and $\mathrm{H} 3.81$.

A preliminary chemical analysis of oreillyite using EDS revealed the presence of Cr only. TEM-EDS spectra extracted from the maps collected on oreillyite in the FIB foil gave (in wt. $\%$ of elements) $\mathrm{Cr} 86.9$ and N 13.1. Electron energy loss spectroscopy (EELS) data (Figure 3) indicate that the valence of $\mathrm{Cr}$ is less than 3 in oreillyite and that the mineral is actually oxygen-free. Chromium in low-Cr and high-Cr parts of the corundum occurs as $\mathrm{Cr}^{3+}$, whereas in oreillyite, $\mathrm{Cr}$ seems to be +1 or +2 . $\mathrm{The} \mathrm{Cr}_{2} \mathrm{~N}$ ideal formula requires $\mathrm{Cr} 88.13$ and $\mathrm{N} 11.87$. 

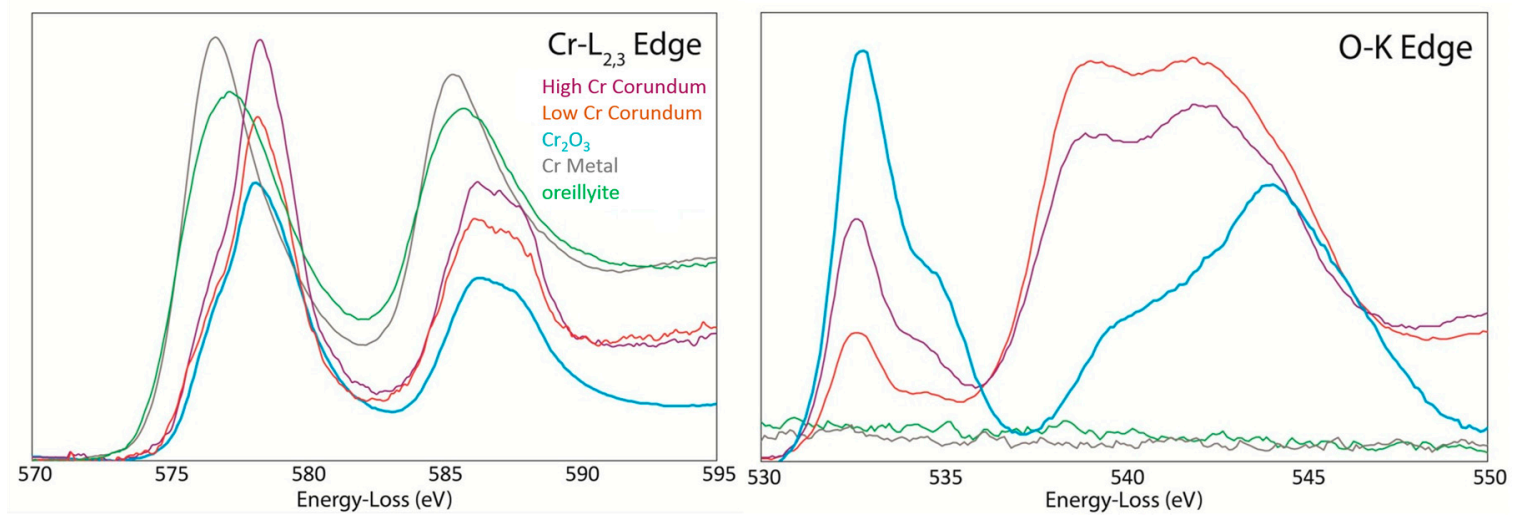

Figure 3. Electron energy loss spectroscopy (EELS) spectra (Cr- $L_{2,3}$ edge, left, O-K edge, right) for different Cr-minerals.

\section{X-ray Crystallography}

The small kishonite fragment in Figure 1 was handpicked from the polished section under a reflected light microscope and mounted on a $5 \mu \mathrm{m}$ diameter carbon fibre, which was, in turn, attached to a glass rod. Then, the fragment was tested by single-crystal X-ray diffraction. Single-crystal X-ray studies were carried out using a Bruker D8 Venture diffractometer equipped with a Photon II CCD detector (Billerica, MA, USA), with graphite-monochromatized MoK $\alpha$ radiation $(\lambda=0.71073 \AA$ ), and with $100 \mathrm{~s}$ exposure time per frame; the detector-to-sample distance was $7 \mathrm{~cm}$. Kishonite is cubic, space group $F m \overline{3} m$, with $a=4.2680(10) \AA, V=77.75(3) \AA^{3}$ and $\mathrm{Z}=4$ [9].

The kishonite structure was solved by direct methods and then refined using the program Shelxl-97 [10]. The site occupation factor (s.o.f.) at the V site was allowed to vary (V vs. Al) using scattering curves for neutral atoms taken from the International Tables for Crystallography [11]. At the last refinement stage, with anisotropic atomic displacement parameters for $\mathrm{V}$, the residual value settled at $R 1=0.0134$ for 25 unique reflections and four parameters. Atom coordinates and isotropic displacement parameters are given in Table 1.

Table 1. Atomic coordinates and equivalent isotropic displacement parameters $\left(\AA^{2} \times 10^{3}\right)$ for kishonite. $U_{\text {eq }}$ is defined as one third of the trace of the orthogonalized $U^{\mathrm{ij}}$ tensor.

\begin{tabular}{cccccc}
\hline Site & $x$ & $\boldsymbol{Y}$ & $\boldsymbol{z}$ & $\boldsymbol{U}_{\mathrm{eq}}$ & s.o.f. \\
\hline $\mathrm{V}$ & 0 & 0 & 0 & $10(2)$ & $\mathrm{V}_{0.96(7)} \mathrm{Al}_{0.04}$ \\
$\mathrm{H}$ & $1 / 4$ & $1 / 4$ & $1 / 4$ & $38(17)$ & $\mathrm{V}_{0.96(7)} \mathrm{Al}_{0.04}$ \\
\hline \multicolumn{5}{c}{ s.o.f. $=$ site occupancy factor. }
\end{tabular}

The crystal structure of kishonite is shown in Figure 4. It is a $\mathrm{CaF}_{2}$ structure type with V in cubic close packing and cubic eight-fold coordination and $\mathrm{H}$ occupying the $T_{\mathrm{d}}$ interstitial sites. V-H bond distance of 1.8481(3) $\AA$. The solution of the crystal structure gave the $\mathrm{VH}_{2}$ stoichiometry, with minor $\mathrm{Al}$ substituting for $\mathrm{V}$ (i.e., $\mathrm{V}_{0.96} \mathrm{Al}_{0.04}$ ), in excellent agreement with the electron microprobe data. The results obtained are also in excellent agreement with what has been reported for synthetic $\mathrm{VH}_{2}$ [12].

As concerns oreillyite, we extracted a grain $(30 \times 38 \times 66 \mu \mathrm{m}$ in size $)$ containing both native chromium and oreillyite (Figure 5) and tried conventional single-crystal X-ray diffraction experiments using a Rigaku XtaLAB Synergy (Tokyo, Japan) with a HyPix detector using MoK $\alpha$ radiation. We collected images with $480 \mathrm{~s}$ of exposure in the $\theta$ range $8.5-27.3^{\circ}$. Oreillyite was present as single crystals, whereas native chromium was present only as a homogeneous polycrystalline material producing rings that were indexed with the $\operatorname{Im} \overline{3} m$ structure of native $\mathrm{Cr}(a=2.889 \AA$; [13]). Oreillyite was indexed with $a=2.7628(3), c=4.4630(6) \AA$, and $V=29.503(6) \AA^{3}$, representing the hexagonal disordered form of $\mathrm{CrN}_{2}$ (space group $P 6_{3} / \mathrm{mmc}$ ) [14-18] with lattice parameters $a=2.748$ and $c=4.438 \AA$. 


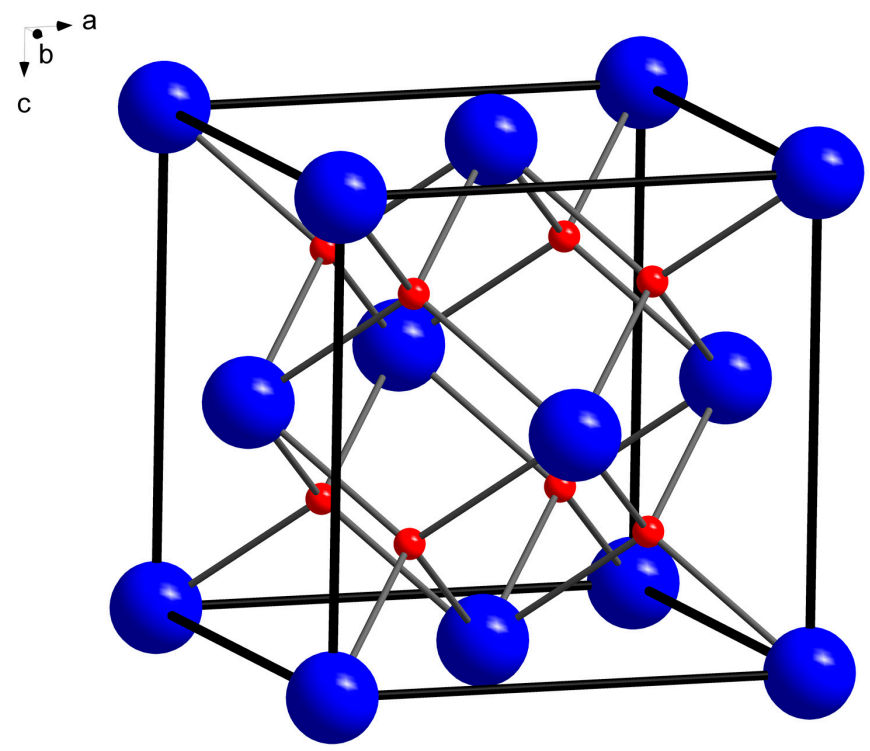

Figure 4. The crystal structure of kishonite. Blue and red spheres correspond to $\mathrm{V}$ and $\mathrm{H}$ atoms, respectively. The unit cell and the orientation of the structure are outlined.

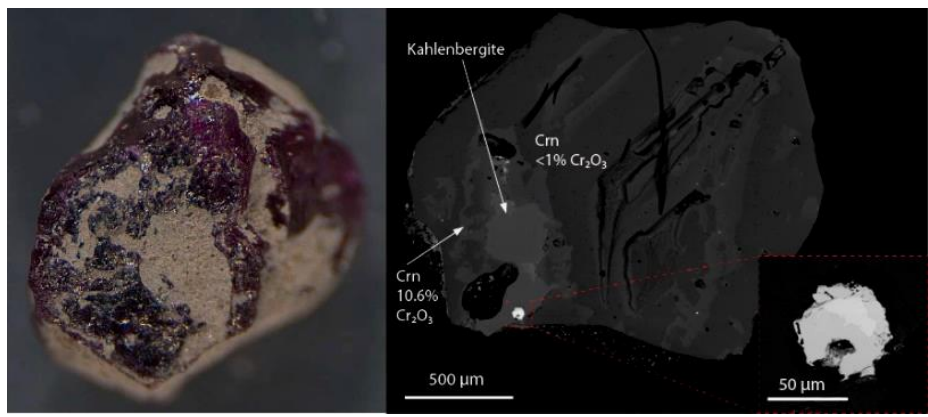

Figure 5. (left) Incident light image of a corundum grain (about $1.7 \mathrm{~mm}$ in size). (right) SEM-BSE image of a portion of the polished area of the corundum grain (Crn) shown on the left where it is visible a bright grain (enlarged in the inset) composed of native chromium (brighter region) and oreillyite (lighter region).

The oreillyite structure was solved by direct methods in the $P 6_{3} / m m c$ space group. It is a hexagonal close packing of $\mathrm{N}$ with $\mathrm{Cr}$ in octahedral coordination. Cr occupies a Wyckoff position $2 c$ and $\mathrm{N}$ partially (nearly $50 \%$ ) occupies a $2 a$ position with $\mathrm{Z}=1$. The ordering of $\mathrm{N}$ in alternating $2 a$ positions leads to the trigonal $P \overline{3} 1 \mathrm{~m}$ structure first reported by Vallas and Calvert [19], which appears as a consequence of aging of disordered h.c.p. $\mathrm{Cr}_{2} \mathrm{~N}$ [20]. Electron densities and geometric details are in keeping with a $\mathrm{Cr}_{2} \mathrm{~N}$ stoichiometry. Atom coordinates and atomic displacement parameters are given in Table 2 . Bond distances are as follows: $\mathrm{Cr}-\mathrm{N}=1.9466(2)(\times 6)$ and $\mathrm{Cr}-\mathrm{Cr}=2.7430(3) \AA$, which compares with values of $1.952 \AA$ and $2.779 \AA$ observed by Cabana et al. [21] for the ordered $P \overline{3} 1 m$ structure.

Table 2. Atomic coordinates and equivalent isotropic displacement parameters $\left(\AA^{2} \times 10^{3}\right)$ for oreillyite. $U_{\text {eq }}$ is defined as one third of the trace of the orthogonalized $U^{\mathrm{ij}}$ tensor.

\begin{tabular}{cccccc}
\hline Site & $x$ & $Y$ & $z$ & $U_{\text {eq }}$ & s.o.f. \\
\hline $\mathrm{Cr}$ & $1 / 3$ & $2 / 3$ & $1 / 4$ & $12(2)$ & 1 \\
$\mathrm{~N}$ & 0 & 0 & 0 & $15(11)$ & $\mathrm{N}_{0.47(9)}$ \\
\hline \multicolumn{6}{c}{ s.o.f. $=$ site occupancy factor. }
\end{tabular}

Crystallographic information files for both kishonite and oreillyite are available as Supplementary Materials. 
Calculated X-ray powder diffraction data (Table 3, in $\AA$ for $\mathrm{CuK} \alpha$ ) for both kishonite and oreillyite are given in Table 3.

Table 3. Calculated X-ray powder diffraction data for kishonite (left) and oreillyite (right). Only reflections with $I_{\text {calc }}>2$ are reported. The strongest reflections are given in bold.

\begin{tabular}{|c|c|c|c|c|c|c|c|c|c|}
\hline$h$ & $k$ & $l$ & $d_{\text {calc }}$ & $I_{\text {calc }}$ & $h$ & $k$ & $l$ & $d_{\text {calc }}$ & $I_{\text {calc }}$ \\
\hline 1 & 1 & 1 & 24.641 & 100 & 1 & 0 & 1 & 30.501 & 3 \\
\hline 2 & 0 & 0 & 21.340 & 42 & 1 & 1 & 0 & 24.055 & 14 \\
\hline 2 & 2 & 0 & 15.090 & 27 & 0 & 0 & 2 & 22.387 & 21 \\
\hline 3 & 1 & 1 & 12.869 & 26 & 2 & -1 & 1 & 21.190 & 45 \\
\hline 2 & 2 & 2 & 12.321 & 7 & 1 & 1 & 1 & 21.190 & 55 \\
\hline 4 & 0 & 0 & 10.670 & 3 & 1 & 1 & 2 & 16.388 & 9 \\
\hline 3 & 3 & 1 & 0.9791 & 10 & 2 & -1 & 2 & 16.388 & 10 \\
\hline 4 & 2 & 0 & 0.9544 & 10 & 3 & 0 & 0 & 13.888 & 16 \\
\hline \multirow[t]{10}{*}{4} & 2 & 2 & 0.8712 & 10 & 1 & 1 & 3 & 12.682 & 6 \\
\hline & & & & & 2 & -1 & 3 & 12.682 & 7 \\
\hline & & & & & 3 & 0 & 2 & 11.802 & 11 \\
\hline & & & & & 2 & 2 & 1 & 11.616 & 4 \\
\hline & & & & & 4 & -2 & 1 & 11.616 & 5 \\
\hline & & & & & 0 & 0 & 4 & 11.193 & 2 \\
\hline & & & & & 4 & -2 & 3 & 0.9365 & 3 \\
\hline & & & & & 2 & 2 & 3 & 0.9365 & 3 \\
\hline & & & & & 4 & 1 & 1 & 0.8910 & 2 \\
\hline & & & & & 3 & 0 & 4 & 0.8715 & 10 \\
\hline
\end{tabular}

\section{Transmission Electron Microscopy (TEM) for Oreillyite}

FIB foils from the region of interest (bottom part of Figure 2) were prepared for TEM using a dual-beam FIB system (FEI Helios G3 CX). High-angle annular dark field scanning transmission electron microscopy (HAADF-STEM) imaging and element mapping were carried out using an FEI Titan G2 80-200 TEM/STEM with ChemiSTEM Technology operating at $200 \mathrm{kV}$ at the Centre for Microscopy, Characterization and Analysis (CMCA), The University of Western Australia, Perth, Australia. The element maps were obtained by energy dispersive $X$-ray spectroscopy using the Super- $X$ detector on the Titan with a probe size $\sim 1 \mathrm{~nm}$ and a probe current of $\sim 0.25 \mathrm{nA}$. Total acquisition times of 20-30 minutes were used to obtain good signal-to-noise ratios. Electron diffraction was carried out using a field limiting aperture that selected an area approximately $600 \mathrm{~nm}$ in diameter.

Synthetic $\mathrm{Cr}_{2} \mathrm{~N}$ can exhibit an ordered $(a=4.81, c=4.48 \AA$; S.G. $P \overline{3} 1 \mathrm{~m})$ or a disordered $(a=2.75$, $c=4.48 \AA$; S.G. $P 6_{3} / m m c$ ) structure [22]. The X-ray study (see above) did not reveal the presence of superstructure reflections leading to the trigonal cell $(P \overline{3} 1 \mathrm{~m}$ model), which were masked by the extremely small size of the crystal and the weak nature of these reflections. The TEM study was, therefore, especially focused to try to elucidate the degree of disorder.

Two selected area electron diffraction (SAED) patterns are shown in Figure 6.

The first (Figure 6a) was matched to the [100] zone axis of the $\bar{P} \overline{3} 1 m C_{2} \mathrm{~N}$ structure [21-23]. The spacings for the two nearest spots making up the rectangle are $4.4 \AA$ (corresponding to the spacing of (001) planes) and $4.1 \AA$ (corresponding to the spacing of (010) planes), in agreement with what observed for the $P \overline{3} 1 \mathrm{~m}$ structure. The other SAED pattern (Figure $6 \mathrm{c}$ ) was matched to the [210] zone axis of the $P \overline{3} 1 m \mathrm{Cr}_{2} \mathrm{~N}$ structure. The spacings for the two nearest spots making up the rectangle are $4.4 \AA$ (corresponding to the spacing of (001) planes) and $2.4 \AA \mathrm{nm}$ (corresponding to the spacing of $(-120)$ planes), again in agreement with that observed for the $P \overline{3} 1 m$ structure. The calculated diffraction patterns for the $P \overline{3} 1 \mathrm{~m}$ structure down the [100] and [210] zone axes (Figure 6b,d) match the experimental SAED patterns in Figure 6a,c. As can be seen, the $4.1 \AA$ spacing we observe (Figure $6 \mathrm{~b}$ ) is only possible with the geometry observed for the trigonal modification (corresponding to the 010 reflection). Even if this reflection should be very weak $\left(I_{\text {calc }}<2\right)$ in the $P \overline{3} 1 m$ structure (see Table 1$)$, its intensity is enhanced because of dynamic effects in the thick foil. 
As additional confirmation, if we take into consideration the $\alpha$ and $\beta$ sample tilts used to obtain the SAED patterns in Figure $6 \mathrm{~b}, \mathrm{c}(\alpha=15.88, \beta=-4.07$ and $\alpha=-14.43, \beta=-1.76$, respectively) it is evident that we tilted approximately $30^{\circ}$ to get from one zone axis to the other. The calculated angle between these two axes in the $P \overline{3} 1 \mathrm{~m}$ space group is actually $30.0^{\circ}$.
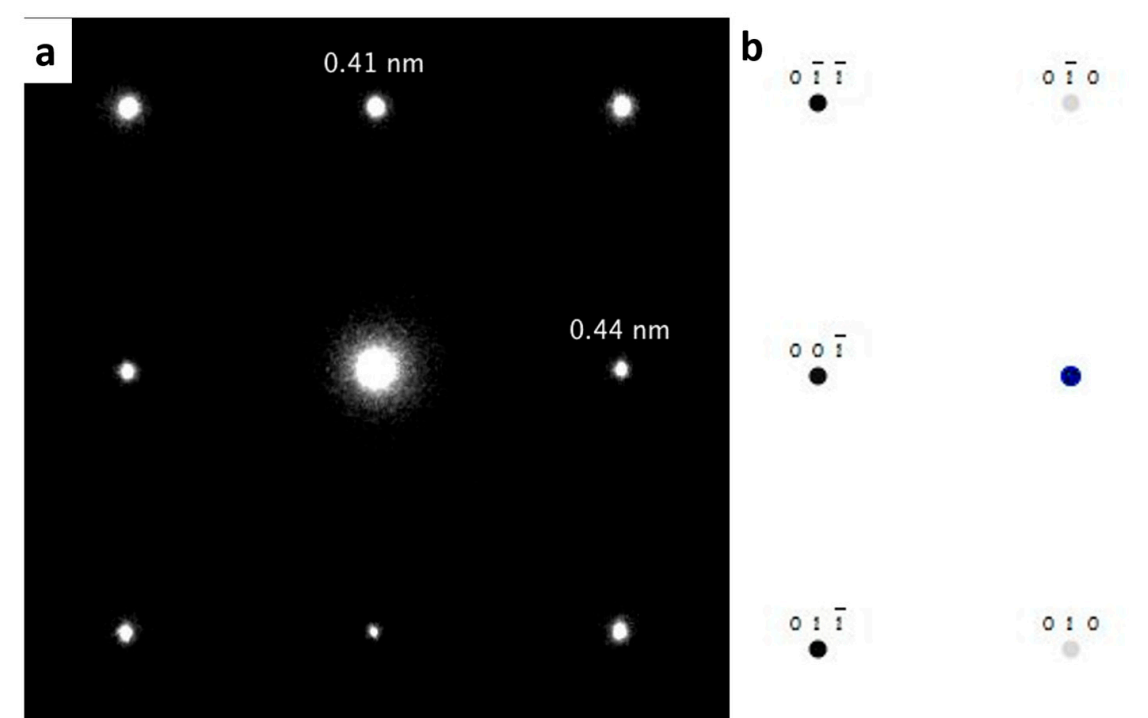

$i^{2}$
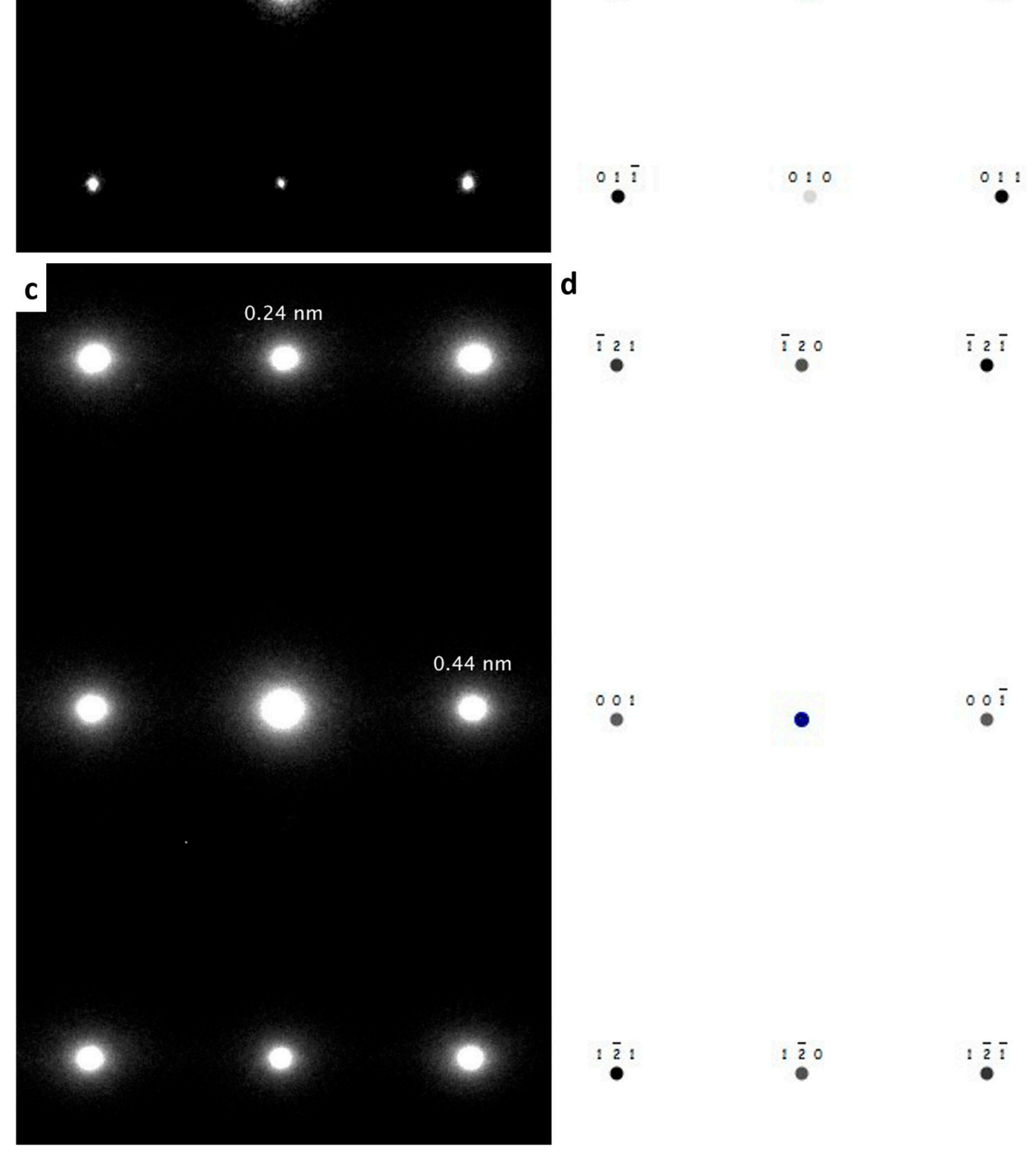

$21 \quad \overline{1} 20$

$\bar{i} 2 \bar{i}$
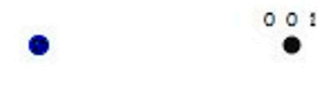

:

$00 \overline{1}$

-

-

$\overline{2} 0$

$2 \overline{2} \bar{i}$

Figure 6. Selected area diffraction patterns for oreillyite down the (a) [100] and (c) [210] zone axes with their equivalent simulated patterns $(\mathbf{b}, \mathbf{d})$, respectively. The experimental patterns were obtained from the same crystal by tilting the sample through an angle of $\sim 30$ degrees. 
Thus, we conclude that oreillyite exhibits the $\varepsilon$-type $P \overline{3} 1 m$ ordered structure (Figure 7 ), although the single-crystal $X$-ray experiment was able to detect only the reflections belonging to the hexagonal substructure. It consists of a hexagonal close-packed (h.c.p.) sublattice of $\mathrm{Cr}$ with interstitial $\mathrm{N}$ atoms occupying some of the octahedral interstices with N-Cr distances of $1.959 \AA$ ([22]; to be compared to 1.9466(2) $\AA$ obtained in the disordered model obtained by single-crystal X-ray diffraction). The trigonal cell of the ordered structure can be obtained from the disordered hexagonal one by applying the transformation matrix $\left|\begin{array}{lllllll}2 & 1 & 0 /-1 & 1 & 0 / 0 & 0 & 1\end{array}\right|$. The cell so obtained for oreillyite is: $a=4.7853(5) \AA$, $c=4.4630(6) \AA, V=88.51 \AA^{3}$, and $Z=3$. Oreillyite is very hard and stable at high-pressure and temperature according to first principles calculations by Ma et al. [23], who calculated a bulk modulus of $289 \mathrm{GPa}$ and a shear modulus of $145 \mathrm{GPa}$ by density functional theory.

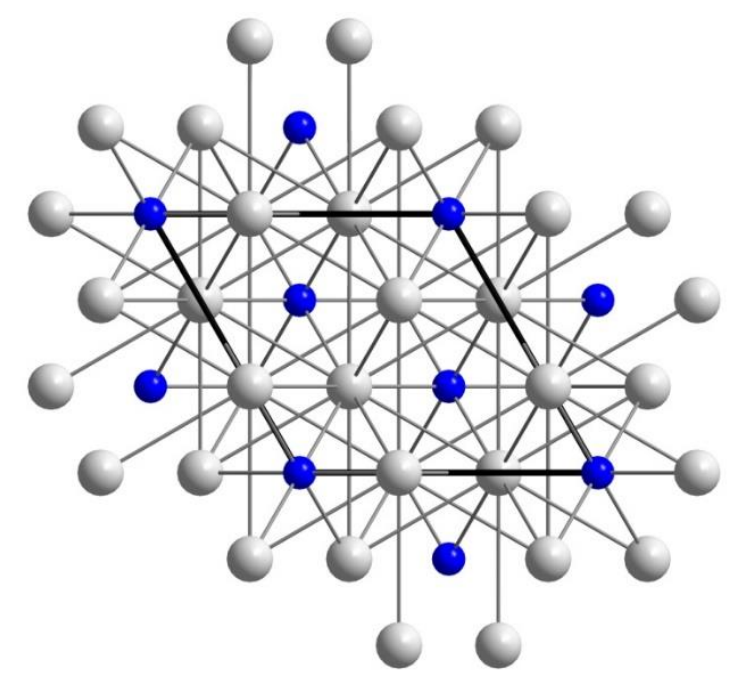

Figure 7. The crystal structure of the ordered form of oreillyite down [001]. Grey and blue circles refer to $\mathrm{Cr}$ and $\mathrm{N}$, respectively.

\section{Remarks on the Origin of Kishonite and Oreillyite}

The coarse (cm-size crystals) V-bearing hibonite + grossite + spinel aggregates containing kishonite appear to represent a late stage of the evolution of this magma [4]. The grain sizes, magmatic microstructures, and evidence for an extended sequence of magmatic crystallization [5,7] clearly rule out more speculative origins such as lightning strikes [24], meteorite impact, or shallow hydrothermal circulation. Petrographic evidence for the reaction liquid + corundum $\rightarrow$ anorthite, and the stability of grossite suggest that this process operated at or near to the base of the crust (25-30 km depth; [3]), and at temperatures ranging from $1450-1500{ }^{\circ} \mathrm{C}$ to a minimum of $>1150{ }^{\circ} \mathrm{C}$.

Oreillyite was found inside a $1.7 \mathrm{~mm}$ crystal of corundum with a hollow centre and raised rims, indicating hopper growth, and with an intense purple-red colour (Figure 2; [5]). The surface of the crystal is decorated with balls of native chromium up to 60 microns across, and very small grains of an Fe-Ni alloy. Corundum is strongly zoned in $\mathrm{Cr}$ from central parts with $1-4 \% \mathrm{Cr}_{2} \mathrm{O}_{3}$, rising to mean values of ca $23 \mathrm{wt}$ \% $\mathrm{Cr}_{2} \mathrm{O}_{3}$ toward both the outer rim and the edge of the central cavity. Single electron microprobe spots in these zones contain up to $33 \% \mathrm{Cr}_{2} \mathrm{O}_{3}$, and corundum adjacent to the chromium balls has mean values $>31 \mathrm{wt}$. $\% \mathrm{Cr}_{2} \mathrm{O}_{3}$. The most $\mathrm{Cr}$-rich portions of the crystal are finely granular in BSE imagery, suggesting an intergrowth of higher- and lower-Cr corundum on the scale of a few microns.

The two ultra-reduced minerals described here imply coexistence with a strongly hydrogendominated fluid [3,4], probably in localized systems isolated from the oxidized lithospheric mantle. Such fluids can be derived from a metal-saturated sublithospheric mantle, where $f \mathrm{O}_{2}$ is buffered near IW, and any $\mathrm{COH}$ fluid consists almost entirely of $\mathrm{CH}_{4}+\mathrm{H}_{2}$; similar fluids are observed in sublithospheric diamonds [25,26] and predicted theoretically [27-29]. The existence of such fluids and 
their movement through the lithosphere could have major implications for the transport of carbon, hydrogen, and other volatile species from the deep mantle to the surface.

Supplementary Materials: The following are available online at http://www.mdpi.com/2075-163X/10/12/1118/s1, CIFs: kishonite and oreillyite.

Author Contributions: SEM, TEM, and EELS studies were carried out by S.E.M.G., W.L.G., J.-X.H., and M.S., L.B. and F.C. performed the X-ray diffraction experiments and electron microprobe analyses. V.T. provided the samples. L.B. wrote the manuscript. All authors have read and agreed to the published version of the manuscript.

Funding: The research was funded by MIUR-PRIN2017, project “TEOREM deciphering geological processes using Terrestrial and Extraterrestrial ORE Minerals", prot. 2017AK8C32 (PI: Luca Bindi), and research funds for the TARDIS Project provided by the ARC Centre of Excellence for Core to Crust Fluid Systems (W.L. Griffin). Ricerca Locale 2014, Università di Milano (PI: Paolo Lotti) and Italian Ministry of Education (MIUR) through the project "Dipartimenti di Eccellenza 2018-2022" (PI: Stefano Poli) provided funding for the instruments used by F. Cámara.

Acknowledgments: We acknowledge the scientific and technical assistance of Microscopy Australia at the Centre for Microscopy, Characterization and Analysis, a facility funded by The University of Western Australia, and State and Commonwealth Governments. Instruments used at Macquarie University were funded by DEST Systemic Infrastructure Grants, ARC LIEF, NCRIS/AuScope, industry partners and Macquarie University. This is contribution 1542 from the ARC Centre of Excellence for Core to Crust Fluid Systems (http://www.ccfs.mq.edu.au) and 1410 from the GEMOC Key Centre (http://www.gemoc.mq.edu.au).

Conflicts of Interest: The authors declare no conflict of interest.

\section{References}

1. Griffin, W.L.; Gain, S.E.M.; Adams, D.T.; Huang, J.-X.; Saunders, M.; Toledo, V.; Pearson, N.J.; O’Reilly, S.Y. First terrestrial occurrence of tistarite $\left(\mathrm{Ti}_{2} \mathrm{O}_{3}\right)$ : Ultra-low oxygen fugacity in the upper mantle beneath Mt. Carmel, Israel. Geology 2016, 44, 815-818. [CrossRef]

2. Griffin, W.L.; Gain, S.E.M.; Huang, J.-X.; Saunders, M.; Shaw, J.; Toledo, V.; O’Reilly, S.Y. A terrestrial magmatic hibonite-grossite-vanadium assemblage: Desilication and extreme reduction in a volcanic plumbing system, Mt Carmel, Israel. Am. Mineral. 2019, 104, 207-219. [CrossRef]

3. Griffin, W.L.; Huang, J.-X.; Thomassot, E.; Gain, S.E.M.; Toledo, V.; O’Reilly, S.Y. Super-reducing conditions in ancient and modern volcanic systems: Sources and behaviour of carbon-rich fluids in the lithospheric mantle. Min. Petrol. 2018, 112, 1-14. [CrossRef]

4. Griffin, W.L.; Gain, S.E.M.; Camara, F.; Bindi, L.; Shaw, J.; Alard, O.; Saunders, M.; Huang, J.-X.; Toledo, V.; O'Reilly, S.Y. Extreme reduction: Mantle-derived oxide xenoliths from a hydrogen-rich environment. Lithos 2020, 358-359, 105404. [CrossRef]

5. Griffin, W.L.; Gain, S.E.M.; Saunders, M.; Cámara, F.; Bindi, L.; Spartà, D.; Toledo, V.; O’Reilly, S.Y. $\mathrm{Cr}_{2} \mathrm{O}_{3}$ in Corundum: Ultra-high contents under reducing conditions. Am. Mineral. 2020, in press.

6. Griffin, W.L.; Gain, S.E.M.; Saunders, M.; Bindi, L.; Alard, O.; Toledo, V.; O'Reilly, S.Y. Parageneses of TiB 2 in corundum xenoliths from Mt Carmel, Israel: Siderophile behaviour of boron under reducing conditions. Am. Mineral. 2020, 105, 1609-1621. [CrossRef]

7. Xiong, Q.; Griffin, W.L.; Huang, J.-X.; Gain, S.E.M.; Toledo, V.; Pearson, N.J.; O’Reilly, S.Y. Super-reduced mineral assemblages in "ophiolitic" chromitites and peridotites: The view from Mt. Carmel. Eur. J. Min. 2017, 29, 557-570. [CrossRef]

8. Huang, J.-X.; Xiong, Q.; Gain, S.E.M.; Griffin, W.L.; Murphy, T.D.; Shiryaev, A.A.; Li, L.; Toledo, V.; Tomshin, M.D.; O'Reilly, S.Y. Immiscible metallic melts in the deep Earth: Clues from moissanite (SiC) in volcanic rocks. Chin. Sci. Bull. 2020, 65, 1479-1488. [CrossRef]

9. Bindi, L.; Cámara, F.; Griffin, W.L.; Huang, J.-X.; Gain, S.E.M.; Toledo, V.; O’Reilly, S.Y. Discovery of the first natural hydride. Am. Mineral. 2019, 104, 611-614. [CrossRef]

10. Sheldrick, G.M. A short history of SHELX. Acta Crystallogr. 2008, A64, 112-122. [CrossRef]

11. Wilson, A.J.C. (Ed.) International Tables for Crystallography; Volume C: Mathematical, physical and chemical tables; Kluwer Academic: Dordrecht, The Netherlands, 1992.

12. Müller, H.; Weymann, K. Investigation of the ternary systems Nb-V-H and Ta-V-H. J. Less Common Metals 1986, 119, 115-126. [CrossRef]

13. Zhu, M.Y.; Liu, Y. Discovery of native chromium in Xizang (Tibet). Chin. Sci. Bull. 1981, 26, 1014-1017. 
14. Andrews, K.W.; Dyson, D.J.; Keown, S.R. Interpretation of Electron Diffraction Patterns; Hilger: London, UK, 1971; p. 203.

15. Kikuchi, M.; Kajihara, M.; Choi, S.K. Cellular precipitation involving both substitutional and interstitial solutes: Cellular precipitation of $\mathrm{Cr}_{2} \mathrm{~N}$ in $\mathrm{Cr}-\mathrm{Ni}$ austenitic steels. Mater. Sci. Eng. A 1991, 146, 131-150. [CrossRef]

16. Presser, R.; Silcock, J.M. Aging behaviour of ${ }^{18} \mathrm{Mn}-{ }^{18} \mathrm{Cr}$ high nitrogen austenitic steels for end rings. Met. Sci. 1983, 17, 241-247. [CrossRef]

17. The Bristol Group. Convergent Beam Electron Diffraction of Alloy Phases; Adam Hilger: Bristol, UK; Boston, MA, USA, 1984; p. 61.

18. Vanderschaeve, F.; Taillard, R.; Foct, J. Discontinuous precipitation of $\mathrm{Cr}_{2} \mathrm{~N}$ in a high nitrogen, chromium-manganese austenitic stainless steel. J. Mater. Sci. 1995, 30, 6035-6046. [CrossRef]

19. Vallas, P.; Calvert, L.D. Pearson's Handbook of Crystallographic Data for Intermediate Phases; ASM Metals Park: Cleveland, OH, USA, 1985; Volume 2, p. 1877.

20. Sundararaman, D.; Shankar, P.; Raghunathan, V.S. Electron microscopic study of $\mathrm{Cr}_{2} \mathrm{~N}$ formation in thermally aged 316ln austenitic stainless steels. Metall. Mater. Trans. A 1996, 27, 1175-1186. [CrossRef]

21. Cabana, J.; Ling, C.D.; Oró-Solé, J.; Gautier, D.; Tobías, G.; Adams, S.; Canadell, E.; Palacín, M.R. Antifluorite-type lithium chromium oxide nitrides: Synthesis, structure, order, and electrochemical properties. Inorg. Chem. 2004, 43, 7050-7060. [CrossRef]

22. Lee, T.-H.; Kim, S.-J.; Takaki, S. On the crystal structure of $\mathrm{Cr}_{2} \mathrm{~N}$ precipitates in high-nitrogen austenitic stainless steel. II. Order-disorder transition of $\mathrm{Cr}_{2} \mathrm{~N}$ during electron irradiation. Acta Crystallogr. 2006, B62, 190-196. [CrossRef]

23. Ma, S.; Liu, Y.; Ye, J.; Zhang, H.; Pang, J. Theoretical study on the elastic, electronic and thermodynamic properties of trigonal-type $\mathrm{Cr}_{2} \mathrm{~N}$ under high pressures. Comp. Mater. Sci. 2014, 5, 620-625. [CrossRef]

24. Ballhaus, C.; Wirth, R.; Fonseca, R.O.C.; Blanchard, H.; Pröll, W.; Bragagni, A.; Nagel, T.; Schreiber, A.; Dittrich, S.; Thome, V.; et al. Ultra-high pressure and ultra-reduced minerals in ophiolites may form by lightning strikes. Geoch. Perspect. Lett. 2017, 5, 42-46. [CrossRef]

25. Smith, E.M.; Shirey, S.B.; Nestola, F.; Bullock, E.S.; Wang, J.; Richardson, S.H.; Wang, W. Large gem diamonds from metallic liquid in Earth's deep mantle. Science 2016, 354, 1403-1405. [CrossRef] [PubMed]

26. Smith, E.M.; Shirey, S.B.; Richardson, S.H.; Nestola, F.; Bullock, E.S.; Wang, J.; Wang, W. Blue boron-bearing diamonds from Earth's lower mantle. Nature 2018, 560, 84-87. [CrossRef] [PubMed]

27. Rohrbach, A.; Ballhaus, C.; Golla-Schindler, U.; Ulmer, P.; Kamenetsky, V.S.; Kuzmin, D.V. Metal saturation in the upper mantle. Nature 2007, 449, 456-458. [CrossRef] [PubMed]

28. Frost, D.J.; McCammon, C.A. The redox state of Earth's mantle. Ann. Rev. Earth Plan. Sci. 2008, 36, 389-420. [CrossRef]

29. Stagno, V.; Ojwang, D.O.; McCammon, C.A.; Frost, D.J. The oxidation state of the mantle and the extraction of carbon from Earth's interior. Nature 2013, 493, 84-88. [CrossRef]

Publisher's Note: MDPI stays neutral with regard to jurisdictional claims in published maps and institutional affiliations.

(C) 2020 by the authors. Licensee MDPI, Basel, Switzerland. This article is an open access article distributed under the terms and conditions of the Creative Commons Attribution (CC BY) license (http://creativecommons.org/licenses/by/4.0/). 